\title{
Controlled trial of combinations of hydroxocobalamin- cystine and riboflavine-cystine, in Nigerian ataxic neuropathy ${ }^{1}$
}

\author{
B. O. OSUNTOKUN, M. J. S. LANGMAN, J. WILSON, \\ A. O. G. ADEUJA, AND M. A. ALADETOYINBO \\ From the Department of Psychiatry and Neurology, University College Hospital, Ibadan, Nigeria, \\ the University Department of Therapeutics, City Hospital, Nottingham, and the \\ M.R.C. Clinical Genetics Research Unit, Institute of Child Health and Institute of Neurology, London
}

SUMMARY Chronic cyanide intoxication of dietary origin and riboflavine deficiency are believed to be major aetiological factors in Nigerian tropical ataxic neuropathy. The results are presented of a double-blind controlled therapeutic trial of combinations of large doses of hydroxocobalamin and cystine as cyanide binding agents together with riboflavine or placebos in Nigerian patients suffering from the tropical ataxic neuropathy. No clinical benefit was demonstrable with any of the treatments.

A syndrome of insidious onset and comprising bilateral optic atrophy, bilateral perceptive deafness, myelopathy, and peripheral neuropathy has been described in many parts of the tropics. It is often referred to as tropical (ataxic) neuropathy.

Chronic cyanide intoxication of dietary origin has been suggested as a major factor in the aetiology of the neuropathy in Nigeria (Monekosso and Wilson, 1966; Osuntokun, 1968, 1969; Osuntokun et al., 1969; Osuntokun, 1971) and in Tanzania (Makene and Wilson, 1972). Deficiency of riboflavine has also been demonstrated in the Nigerian patients (Osuntokun, 1968; Aladetoyinbo et al., 1971). However, no benefit could be demonstrated in a controlled clinical trial from treatment with hydroxocobalamin (which has a strong affinity for cyanide in vitro and has a demonstrable protective effect in acute cyanide poisoning), while any effect of riboflavine was small and statistically insignificant (Osuntokun et al., 1970).

Sulphur-containing amino acids (cystine and cysteine) are thiol donors which combine with cyanide to form thiocyanate, an important pathway in man for detoxicating cyanide. In addition, plasma concentrations of cysteine and cystine

1 This study was supported by a grant from the Wellcome Trust. have been found to be reduced in Nigerian ataxic neuropathy (Osuntokun et al., 1968), and it therefore seemed worthwhile to examine the value of cystine in treatment. It was combined with hydroxocobalamin in five times the dose previously used as a second cyanide binding agent. A second group received cystine plus riboflavine injections, the latter being added to determine if the previous mildly beneficial effect attributable to this drug was a consistent finding. The riboflavine injections were dyed so as to be indistinguishable from the vitamin $B_{12}$ and the results in these test groups were compared with those obtained in a control group receiving placebo tablets and $1 \mu \mathrm{g}$ only of cyanocobalamin by injection.

\section{METHODS}

The subjects were 51 patients who showed the clinical features of the ataxic neuropathy as previously described (Osuntokun, 1968, 1969). Of these 36 took part in the previous trial (Osuntokun et al., 1970). In the nine month interval between the end of the first trial and the beginning of the second, they received non-specific treatment which did not include administration of vitamin $B_{12}$, riboflavine, or aminoacid supplements and they continued to subsist on cassava meals eaten usually three or more times a 
day. The rest of the subjects were newly diagnosed cases, and had not previously received any form of conventional treatment. Advanced cases were not included in the trial. The patients were seen weekly at the Neuropathic Research Clinic maintained by the Wellcome Trust at Epe, or in the Neurology Clinic at the University College Hospital, Ibadan. During the trial, the patients remained on their normal diet comprising usually cassava meals eaten three or more times a day. The procedure employed in the trial was as previously described (Osuntokun et al., 1970). The three treatment groups, to which patients were randomly allocated, received (1) weekly injections of $5,000 \mu \mathrm{g}$ hydroxobalamin plus cystine tablets $500 \mathrm{mg}$ daily, (2) weekly injections of $5 \mathrm{mg}$ riboflavine dyed with amaranth (to resemble hydroxocobalamin) plus cystine tablets $500 \mathrm{mg}$ daily, and (3) weekly injections of $1 \mu \mathrm{g}$ cyanocobalamin plus a placebo tablet identical with the cystine tablet, and given daily. The allocation to treatment groups was determined by a prearranged schedule prepared by M.J.S.L. The patients themselves and their examiner (B.O.O.) were unaware of any difference of treatment. The duration of treatment was 48 weeks. Clinical assessment was completed before and after trial as previously described (Osuntokun et al., 1970). Improvement or deterioration during the trial was represented by a reduction or an increase in the score respectively. Plasma thiocyanate concentrations were estimated as previously described (Osuntokun et al., 1970).

\section{RESULTS}

Of the 51 patients who commenced the trial, seven failed to complete the full treatment period. Four of these were on hydroxocobalamincystine, two on riboflavine-cystine, and one on cyanocobalamin-placebo tablets.

Table 1 shows that three groups were comparable with regard to age, sex, and initial

TABLE 1

COMPARABILITY OF PATIENTS GIVEN THE THREE TREATMENTS

\begin{tabular}{|c|c|c|c|}
\hline & \multicolumn{3}{|c|}{ Treatment groups } \\
\hline & $\begin{array}{c}\text { Hydroxocobalamin } \\
+ \\
\text { cystine }\end{array}$ & $\begin{array}{c}\text { Riboflavine } \\
+ \\
\text { cystine }\end{array}$ & $\begin{array}{c}\text { Cyanocobalamin } \\
+ \\
\text { placebo tablets }\end{array}$ \\
\hline \multirow{2}{*}{$\begin{array}{l}\text { Men } \\
\text { Women } \\
\text { Mean age (yr) } \\
\text { Mean initial neuro- } \\
\text { logical score }\end{array}$} & $\begin{array}{c}14 \\
4 \\
53 \cdot 9\end{array}$ & $\begin{array}{c}12 \\
5 \\
51 \cdot 0\end{array}$ & $\begin{array}{l}6 \\
10 \\
46 \cdot 6\end{array}$ \\
\hline & $117 \cdot 2$ & $133 \cdot 2$ & $140 \cdot 6$ \\
\hline
\end{tabular}

TABLE 2

OVERALL RESULTS OF NEUROLOGICAL ASSESSMENT SCORES

\begin{tabular}{lc} 
Treatment group & $\begin{array}{c}\text { Mean percentage change } \\
\text { in neurological scores }\end{array}$ \\
\hline Hydroxocobalamin + cystine & $+8 \cdot 1$ \\
Riboflavine + cystine & $-4 \cdot 0$ \\
Cyanocobalamin placebo + cystine placebo & $-4 \cdot 2$
\end{tabular}

The percentage change in neurological score for each patient was calculated-for example, initial score $=50$, final score $=60$, percentage change $=20 \%$ in deterioration or $+20 \%$. The mean of these figures was calculated. Positive changes indicate deterioration. Negative changes represent improvement.

$\left.\begin{array}{l}\text { (1) } v \text {. (3) } 0.1>\mathrm{P}>0.05 \\ \text { (1) } v \text {. (2) } 0.1>\mathrm{P}>0.05\end{array}\right\}$ Mann Whitney $\mathrm{U}$ test.

TABLE 3

SUBJECTIVE CHANGES AT END OF TRIAL

\begin{tabular}{lccccc}
\hline Treatment groups & Better & No change & Worse & Total \\
\hline Hydroxocobalamin + cystine & 4 & 5 & 5 & 14 \\
Riboflavine + cystine & 11 & 1 & 3 & 15 \\
Cyanocobalamin + placebo & 10 & 3 & 2 & 15 \\
\hline
\end{tabular}

TABLE 4

MEAN THIOCYANATE CONCENTRATIONS BEFORE AND AFTER TRIAL IN THOSE INDIVIDUALS IN WHOM PAIRED MEASUREMENTS WERE MADE

\begin{tabular}{lccc}
\hline Treatment groups & No. & \multicolumn{2}{c}{$\begin{array}{c}\text { Mean plasma concentration } \\
(\mu \mathrm{mol} / \mathrm{100} \mathrm{ml} . \pm S E M)\end{array}$} \\
\cline { 2 - 4 } & & Before trial & At end of trial \\
\hline Hydroxocobalamin + cystine & 14 & $11 \cdot 0 \pm 1 \cdot 2$ & $8 \cdot 2 \pm 1 \cdot 0$ \\
Riboflavine + cystine & 15 & $8 \cdot 7 \pm 0.9$ & $8 \cdot 4 \pm 0.9$ \\
Cyanocobalamin + cystine & 14 & $10 \cdot 4 \pm 1 \cdot 2$ & $8 \cdot 5 \pm 1 \cdot 3$ \\
\hline
\end{tabular}

neurological score, except that the cyanocobalamin-placebo tablets group contained a high proportion of women.

Table 2 shows that treatment with hydroxocobalamin-cystine and riboflavine-cystine did not have any beneficial effect compared with placebo (cyanocobalamin-placebo tablets). Although the group treated with cyanocobalaminplacebo tablets contained more women than the other two groups, this was unlikely to have affected the results of the final assessment, for there was no significant difference between the changes in percentage neurological scores in men 
TABLE 5

DISTRIBUTION OF PATIENTS TREATED IN BOTH THE FIRST AND SECOND TRIALS

\begin{tabular}{lccc}
\hline First trial & \multicolumn{4}{c}{ Second trial } \\
\cline { 2 - 4 } & $\begin{array}{c}\text { Hydroxocobalamin } \\
+\end{array}$ & $\begin{array}{c}\text { Riboflavine } \\
+\end{array}$ & $\begin{array}{c}\text { Cyanocobalamin } \\
+\end{array}$ \\
& cystine & cystine & placebo tablets \\
\hline Hydroxocobalamin & 6 & 3 & 7 \\
Riboflavine & 3 & 3 & 4 \\
Cyanocobalamin & 2 & 5 & 2 \\
\hline & 11 & $12 *$ & 13
\end{tabular}

Mean change in neurological

score between

end of first and

start of second

trial

$+6.4$

$+6 \cdot 8$

$+1 \cdot 5$

* The treatment in the first trial for one patient in this treatment group is not known.

and women $(-0.6$ and +1.4 for the mean percentage changes in the 28 men and 16 women respectively who completed the trial).

At the end of the trial, patients were asked whether they considered that they had benefited from the treatment. Table 3 shows the results, which are comparable with those obtained with neurological scoring. Plasma thiocyanate levels tended to fall during the trial and the greatest change recorded was in patients taking hydroxocobalamin plus cystine. However, this fall was little greater than in patients given a very small (placebo) dose of cyanocobalamin plus placebo tablets (Table 4).

Re-randomization resulted in an even distribution of patients in the first trial (Table 5) to the groups in the second trial.

\section{DISCUSSION}

The results of this study have shown that treatment with hydroxocobalamin in combination with cystine or riboflavine in combination with cystine is not beneficial in established Nigerian ataxic neuropathy.

Although the results are similar to our pre- vious therapeutic trial mentioned earlier, both studies contrast with the benefit said to occur after admission of the patients to hospital. Empirical treatment regimens in hospital usually comprise oral or parenteral administration of $\mathbf{B}$ complex vitamins coupled with a more varied diet than that ordinarily consumed by the patients.

The failure of treatment in the field may depend more on the severity of dietary cyanide or cyanogen exposure than upon the failure of detoxication mechanisms, although this remains a possibility.

Therapeutic trials in experimental animals are now in progress. The problems of altering entrenched dietary habits are too formidable to make dietary trials feasible at present.

We are grateful to Glaxo laboratories for providing the therapeutic agents and placebo.

\section{REFERENCES}

Aladetoyinbo, M. A., Osuntokun, B. O., and Adeuja, A. O. G. (1971). Serum riboflavin in the Nigerian nutritional ataxic neuropathy. West African Journal of Biological and Applied Chemistry, 14, 3-5.

Makene, W. J., and Wilson, J. (1972). Biochemical studies in Tanzanian patients with ataxic tropical neuropathy. Journal of Neurology, Neurosurgery, and Psychiatry, 35, 31-33.

Monekosso, G. L., and Wilson, J. (1966). Plasma thiocyanate and vitamin $B_{12}$ in Nigerian patients with degenerative neurological disease. Lancet, 1, 1062-1064.

Osuntokun, B. O. (1968). An ataxic neuropathy in Nigeria. A clinical, biochemical and electrophysiological study. Brain, 91, 215-248.

Osuntokun, B. O. (1969). Chronic Cyanide Intoxication and a Degenerative Neuropathy in Nigeria. Ph.D. Thesis: University of Ibadan.

Osuntokun, B. O. (1971). Epidemiology of tropical nutritional neuropathy in Nigerians. Transactions of the Royal Society of Tropical Medicine and Hygiene, 65, 454-479.

Osuntokun, B. O., Durowoju, J. E., McFarlane, H., and Wilson, J. (1968). Plasma amino-acids in the Nigerian nutritional ataxic neuropathy. British Medical Journal, 3, 647-649.

Osuntokun, B. O., Langman, M. J. S., Wilson, J., and Aladetoyinbo, A. (1970). Controlled trial of hydroxocobalamin and riboflavine in Nigerian ataxic neuropathy. Journal of Neurology, Neurosurgery, and Psychiatry, 33, 663-666.

Osuntokun, B. O., Monekosso, G. L., and Wilson, J. (1969). Relationship of a degenerative tropical neuropathy to diet. British Medical Journal, 1, 547-550. 